\title{
MIXED LIGAND COMPLEXES OF IRON(II) AS NONAQUEOUS ACID-BBASE AND AQUEOUS OXIDATION-REDUCTION INDICATORS
}

\author{
AJ IसIED A. SCHII,
}

Department of Chemistry. University of Michigan, Ann Arbor, Mich. (U.S..A.)

(Reccived Maty 5th, 10601 )

Studies conducted on the preparation and properties of the complexes of iron(II) and (III) with cyanide and aromatic cliimine mixed ligands ${ }^{1-3}$ indicate that they may be useful in a varicty of ways in chemical analysis. Thus far analytical use has been made only of the ncutral dicyano-bis-(I, IO-phenanthroline)-iron(II) complex and of its 4,7-diphenyl-1,10-phenanthroline homolog. A highly selective, sensitive colorimetric method for the determination of cyanide based on formation and extraction of the former has been described ${ }^{4}$. The homologous phenyl-substituted complex was shown to be a suitable form in which trace amounts of iron can be quantitatively separated from copper and measured spectrophotometricallys. In the present study it is found that dicyano-bis-(I,IO-phenanthroline)-iron(II) and dicyano-bis$\left(2,2^{\prime}\right.$-bipyridine)-iron(II) are useful as acid-base and oxidation-reduction indicators. Future studies are anticipated which may lead to the use of the charged species in this serics of mixed ligand complexes as precipitation reagents. The tetracyano-mono-( $I$, Io-phenanthroline)-ferrate(II) anion, for example, which forms insoluble silts with a number of the heavy metal ions, may prove to be a practical and selective precipitation reagent. The tetracyano complex and its salts are highly colored; thus small amounts could be measured colorimetrically.

For simplicity and convenience, the trivial names ferrocyphen and ferrocypyr are proposed for dicyano-bis-( $x$, ro-phenanthroline)-iron(II) and dicyano-bis-(2,2'bipyricline)-iron(II), respectively; the cationic iron(III) species, obtained on oxidation of these neutral complexes, may then be referred to respectively as ferricyphen and ferricypyr.

It is believed that this marks the first time a metal complex of any kind has been found to be effective as an acid-base indicator. In any case, the use of a metal complex for such a purpose is sufficiently novel to prompt some elaboration as to its conception. During a recent investigation ${ }^{3}$ it was found that ferrocyphen and ferrocypyr react rapidly and reversibly with strong acids to give stable mono-and diprotonated species. Acid exchange measurements, carried out in glacial acetic acid, indicated that ferrocyphen and ferrocypyr are similar to o-chloroaniline in basicity. In acetic acid solvent, the monoprotonated species proved to be very much iveaker than o-chloroaniline, somewhat weaker than thiourea, yet considerably stronger than the solvent in competition for perchloric acid. Since the visible absorption characteristics, as well as the basicities, of the protonated and neutral species differ markedly, the neutral complexes should be able to function as acid-base indicators. This 
contention is confirmed by the results of the present study. It is shown that the complexes are applicable as indicators for titrating certain bases in various nonaqueous solvents. Their possible applications in spectrophotometric titrations and in aqueous systems have yet to be investigated.

Formal redox potentials for ferrocyphen and ferrocypyr were measured in various concentrations of sulfuric acid. Confirming the fact that only the iron(II) species exhibit measurable basicities, the formal potentials are found to increase with increasing acid concentration. Interestingly, just the opposite trend is observed for the formal potentials of the ferroin complexes tris-(I,IO-phenanthroline)-iron(II), tris-(5-nitro-r, 10-phenan throline)-iron(I I), etc. ${ }^{6}$.

The results of this investigation show the neutral mixed ligand complexes of iron(II) to be suitable for use as redox indicators. Several practical titrations are described. The suitability of ferrocyphen as an indicator for the titration of aromatic amines with sodium nitrite is especially notable.

Previous work has been reported concerning the properties of the tetracyano species. GeORGE, HaNANIA AND IRVINE? found a value of $0.54 \mathrm{I} V$ for the standard reduction potential of the following couple (where bipy represents $2,2^{\prime}$-bipyridine):

$$
\left[\text { lic bipy }(\mathrm{CN})_{-1}\right]-+\mathrm{e}=\left[\mathrm{lic} \text { bipy }(\mathrm{CN})_{3}\right]^{-2}
$$

In $0.2 M \mathrm{HCl}$ a formal potential of $0.6 \mathrm{ry} \mathrm{V}$ was found. More positive potentials arise in acid because the iron(II) complex forms stable acid species whereas the iron(III) complex does not. The visible absorption characteristics of the iron(II) and iron(III) tetracyano species are not greatly different; hence they are not believed to be suitable redox indicators. They could find application in spectrophotometric titrations, but this possibility has yet to be explored.

An interesting trend is apparent in the formal redox potentials of the complexes: a decrease in potential of approximately $0.2 \mathrm{~V}$ results each time an aromatic diimine ligand is displaced from coordination with iron by two cyanide ligands. To illustrate, complexes in the iron-cyanide-2,2'-bipyridine system and their approximate formal

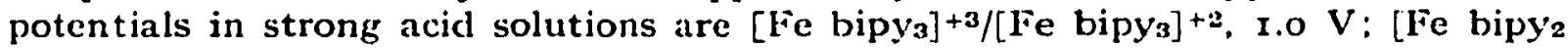
$\left.(\mathrm{CN})_{2}\right]+/\left[\mathrm{Fe} \operatorname{bipy}_{2}(\mathrm{CN})_{2}\right]_{,}, 0.8 \mathrm{~V} ; \quad\left[\mathrm{Fe} \operatorname{bipy}(\mathrm{CN})_{4}\right]-/\left[\mathrm{Fe} \text { bipy }(\mathrm{CN})_{4}\right]^{-2}, \quad 0.6 \mathrm{~V} ;[\mathrm{Fe}$ $\left.(\mathrm{CN})_{0}\right]^{-3} /\left[\mathrm{Fe}(\mathrm{CN})_{0}\right]^{-4}, 0.4 \mathrm{~V}$.

\section{APİARATUS AND REAGENTS}

A Beckman pH meter, Model G, was used for potentiometric titrations. For nonaqueous acid - base titrations a conventional glass electrode and silver-silver chloride reference electrode were used. When titrations were performed in acetic anhydride the silversilver chloride electrode was immersed in a saturated acetic anhydricle solution of silver and lithium chlorides which was in electrical contact with the solution titrated by means of a capillary-fibre junction". For all other titrations the reference electrode was immersed directly in the solution titrated. A platinum electrode anid saturated calomel reference electrode (fibre-capillary type) were employed for aqueous redox titrations.

Procedural details for the synthesis of dicyano-bis-(r, ro-phenanthroline)-iron(II) dihydrate (ferrocyphen) and dicyano-bis-(2,2'-bipyridine)-iron(II) trihydrate (fcrrocypyr) are given elsewhere. Solutions of the solid complexes were prepared as indicators. For acid-base titrations, $25 \mathrm{mg}$ of the solid complex was dissolved in roo $\mathrm{ml}$ 
of the solvent to be used for the titration and $\mathrm{r} \mathrm{ml}$ of this indicator solution added to approximately every $25 \mathrm{ml}$ of solution to be titrated. For aqueous redox titrations, $0.3 \mathrm{~g}$ of the solid complex was clissolved in $100 \mathrm{ml}$ of concentrated acid, of the kind to be used in the titration, and $\mathrm{I} \mathrm{ml}$ of this inclicator solution was added to approximately every roo $\mathrm{ml}$ of solution to be titrated. Limited solubilities preclude preparation of more concentrated indicator solutions in both cases.

The nonaqucous solvents used were of reagent quality; no basic impurities were detectable.

Standard perchloric acid in acetic acid

A $0.1 M$ solution was prepared by the method of FrIT\%" and standardized by potentiometric titration against potassium acid phthalate in acctic acid.

Standard perchloric acid in acetic anhydride-acetic acid mixture

A $0.05 M$ solution was prepared as described by STREUL, ${ }^{8}$ and standarclized with potassium acid phthalate by potentiometric titration in acetic acid.

\section{Standard ceric sulfate solution}

A solution $0.05 M$ in cerium(IV) and approximately $0.9 M$ in $\mathrm{H}_{2} \mathrm{SO}_{4}$ was prepared using ceric hydroxide (G. Frederick Smith Chemical Co.) and the procedure clescribed by DIEHL AND SMITH'10. Arsenious oxide was cmployed for standardization.

\section{Standard potassium dichromate, o.I $\mathrm{N}$}

This was prepared by dissolving a weighed sample of dry, primary standard grade $\mathrm{K}_{2} \mathrm{Cr}_{2} \mathrm{O}_{7}$ and diluting to a known volume with distilled water.

Standard vanadium(V) solution, $0.02 \mathrm{M}$

A $2.4-\mathrm{g}$ sample of ammonium vanadate was dissolved in $16 \mathrm{ml}$ of concentrated sulfuric acid and cliluted to I 1 with distilled water. The molarity of the final solution was determined by potentiometric titration versis a standardized solution of ferrous ammonium sulfate.

Sodizun nitrite solution, o.I $M$

Reagent grade $\mathrm{NaNO}_{2}$ was dried at $110^{\circ}$ for $2 \mathrm{~h}$; a weighed sample was dissolved and diluted to exactly I 1 with distilled water; the molarity was calculated, assinming absolute purity.

\section{EXPERIMENTAL.}

Acid-base titrations in nonaqueons solvents

Preliminary tests were carried out to determine which solvents of those commonly employed for nonacucous titrations might prove suitable in conjunction with the use of the neutral complexes as indicators. Criteria for suitability were the following: $(I)$ the solvent should dissolve a sufficient amount of the complex to be colored thereby, (2) the addition of I-3 drops of the $0 . I M$ perchloric acid titrant to the solution should result in a pronounced and easily recognized color change, and (3) the color change should be reversible on adcling a weak basc. Acetone, dioxane, ethyl 
acetate, and benzene failed to dissolve the complexes. Varying degrees of solubility. were observed in isopropyl alcohol, ethylene glycol, and diethyl cellosolve; however excessive amounts of acid were necessary to produce significant color changes. Solvents which provicled all of the sought-for characteristics are glacial acetic acid, acetic anhydricle, chloroform, chlorobenzene, nitrobenzene, nitromethane, and acetonitrile.

A variety of titrations were performed to evaluate the applicability and effectiveness of ferrocyphen and ferrocypyr as acid-bases indicators. Four different solvents and a number of selected weak basts were employed. The general procedure was the same in every case. Table I gives the pertinent data and results.

].A 13I.1: 1

MrRATIONS IN NONAQLFOL'S SOLVENTS

\begin{tabular}{|c|c|c|c|c|c|c|c|c|c|}
\hline \multirow{2}{*}{ Solvent } & \multirow{2}{*}{$\begin{array}{c}\text { Siusstanter } \\
\text { litrated }\end{array}$} & \multirow{2}{*}{$\begin{array}{l}\text { R for } \\
\text { alliquint }\end{array}$} & \multirow{2}{*}{ Mrlhode } & \multicolumn{4}{|c|}{ 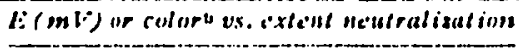 } & \multirow{2}{*}{\multicolumn{2}{|c|}{ 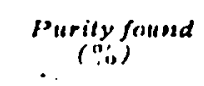 }} \\
\hline & & & & 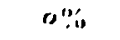 & $.500 \%$ & $109 \%$ & $211 \%$ & & \\
\hline Acetic acid & $\left.\mathrm{NaC}_{2} \mathrm{H}_{3} \mathrm{C}\right)_{2}$ & $0.288_{5}$ & $\begin{array}{l}\text { pot } \\
\text { phen } \\
\text { pyi }\end{array}$ & $\begin{array}{l}185 \\
12 \\
11\end{array}$ & $\begin{array}{l}230 \\
12 \\
11\end{array}$ & $\begin{array}{l}363 \\
(1)\end{array}$ & $\begin{array}{l}511 \\
y \\
y\end{array}$ & $\begin{array}{l}99.6 \\
99.5 \\
99.4\end{array}$ & 99.6 \\
\hline Acctic acicl & lygrelines & 0.27 .50 & $\begin{array}{l}\text { pest } \\
\text { phen } \\
\text { lyser }\end{array}$ & $\begin{array}{l}18(s) \\
12 \\
1\end{array}$ & $\begin{array}{l}215 \\
12 \\
11\end{array}$ & $\begin{array}{l}35^{\circ} \\
12 \\
I^{\prime}\end{array}$ & $\begin{array}{l}55^{\circ} \\
3^{\circ} \\
5\end{array}$ & $\begin{array}{l}99.1 \\
90.1 \\
99.0\end{array}$ & 99.1 \\
\hline Acctic acid & I-Naphthylamine & 0.1273 & $\begin{array}{l}\text { pot } \\
\text { plown } \\
\text { yy'r }\end{array}$ & $\begin{array}{l}100 \\
18 \\
1\end{array}$ & $\begin{array}{l}218 \\
12 \\
13\end{array}$ & $\begin{array}{l}3.46 \\
\text { (1) }\end{array}$ & $\begin{array}{l}492 \\
10\end{array}$ & $\begin{array}{l}99.5 \\
99.5 \\
99.7\end{array}$ & 99.7 \\
\hline Acetic acicl & $p-13 r o m u a n$ niline. & $0.50+5$ & $\begin{array}{l}\text { pot } \\
\text { phen } \\
\text { pys }\end{array}$ & $\begin{array}{l}192 \\
12 \\
12\end{array}$ & $\begin{array}{l}219 \\
12 \\
11\end{array}$ & $\begin{array}{c}352 \\
\mathbf{U} \\
\text { pale R }\end{array}$ & $4^{83}$ & $\begin{array}{l}99.0 \\
98.8 \\
98.3\end{array}$ & $\begin{array}{l}98.1 \\
98.7\end{array}$ \\
\hline Acctic aciol & "-Chloroaniline: & 0.3544 & $\begin{array}{l}\text { pot } \\
\text { phes } \\
\text { jus }\end{array}$ & $\begin{array}{l}280 \\
12 \\
13\end{array}$ & $\begin{array}{l}32.4 \\
12\end{array}$ & $\begin{array}{l}1.46 \\
\text { () } 10 \\
\text { () } 10\end{array}$ & $\begin{array}{l}495 \\
5 \\
5\end{array}$ & $\begin{array}{r}99.3 \\
99.6 \\
100.1\end{array}$ & 08.7 \\
\hline Acctic acid & 2.4-1)ichloro-aniline & $0.175^{6}$ & $\begin{array}{l}\text { pest } \\
\text { phen } \\
\text { pyr }\end{array}$ & $\begin{array}{l}337 \\
12 \\
11\end{array}$ & $\begin{array}{l}380 \\
(0 \\
0\end{array}$ & $\begin{array}{l}+72 \\
6 Y \\
6 Y\end{array}$ & $\begin{array}{l}4^{89} \\
y^{\circ}\end{array}$ & $\begin{array}{l}98.1 \\
96 \\
99\end{array}$ & \\
\hline Acetic anhyedricie & $1 . i<1$ & 0.0118 & $\begin{array}{l}\text { potat } \\
\text { phen } \\
\text { pys }\end{array}$ & $\begin{array}{l}420 \\
13 \\
1\end{array}$ & $\begin{array}{l}516 \\
13\end{array}$ & $\begin{array}{l}715 \\
01\end{array}$ & $\begin{array}{l}910 \\
y^{\prime}\end{array}$ & $\begin{array}{l}79.5 \\
80.1 \\
78.1\end{array}$ & \\
\hline Acctic anhyclricle & II I3r & 0.0174 & $\begin{array}{l}\text { poted } \\
\text { phen } \\
\text { pyr }\end{array}$ & $\begin{array}{l}40 \\
1 \\
1\end{array}$ & $\begin{array}{l}683 \\
0\end{array}$ & $\begin{array}{l}880 \\
y^{\prime}\end{array}$ & $\begin{array}{l}966 \\
Y \\
Y\end{array}$ & $\frac{99}{-}$ & \\
\hline Acetic anhydride & $\mathrm{Nan}\left({ }_{2} \mathrm{H}_{3}()_{2}\right.$ & 0.0257 & $\begin{array}{l}\text { potd } \\
\text { plien } \\
\text { pyr }\end{array}$ & $\begin{array}{l}299 \\
13 \\
1\end{array}$ & $\begin{array}{l}390 \\
13 \\
V\end{array}$ & $\begin{array}{c}619 \\
\text { R } \\
\text { palle IR }\end{array}$ & $\begin{array}{l}960 \\
y \\
y\end{array}$ & $\begin{array}{r}99.9 \\
100.1 \\
100.3\end{array}$ & $0 \Omega .9$ \\
\hline Acetic anhyedricle & l'yricline & 0.0204 & $\begin{array}{l}\text { pota } \\
\text { phen } \\
\text { pyr }\end{array}$ & $\begin{array}{l}3^{3} \\
1^{2} \\
V\end{array}$ & $\begin{array}{l}484 \\
17\end{array}$ & $\begin{array}{l}079 \\
0 \\
01\end{array}$ & $\begin{array}{l}935 \\
Y\end{array}$ & $\begin{array}{l}99.0 \\
98.7 \\
98.5\end{array}$ & 98.0 \\
\hline
\end{tabular}


TABIE I (COnt.)

\begin{tabular}{|c|c|c|c|c|c|c|c|c|c|}
\hline \multirow{2}{*}{ Solvene } & \multirow{2}{*}{$\begin{array}{c}\text { Substanse } \\
\text { bitraled }\end{array}$} & \multirow{2}{*}{$\begin{array}{l}\text { pper } \\
\text { aliquol }\end{array}$} & \multirow{2}{*}{ methride } & \multicolumn{4}{|c|}{ E(mV) or coloro ys. extent neturalization } & \multirow{2}{*}{\multicolumn{2}{|c|}{ 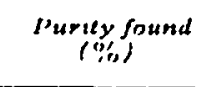 }} \\
\hline & & & & o", & $50 \% \%$ & 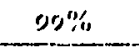 & $200 \%$ & & \\
\hline Chioroform & Pyridine & 0.3089 & $\begin{array}{l}\text { pot } \\
\text { phen } \\
\text { pyr }\end{array}$ & $\begin{array}{l}y^{3.42} \\
13\end{array}$ & $\begin{array}{l}2 \mathbf{2 3} \\
\mathbf{P} \\
\mathbf{B}\end{array}$ & $\begin{array}{l}343 \\
R \\
1\end{array}$ & $\begin{array}{l}565 \\
Y \\
Y\end{array}$ & $\begin{array}{l}99.0 \\
99.0 \\
99.1\end{array}$ & $\begin{array}{l}99.0 \\
99.0\end{array}$ \\
\hline Chloroform & 1,10-1'henanthrolince & 0.0628 & $\begin{array}{l}\text { pot } \\
\text { phen } \\
\text { pyrr }\end{array}$ & $\begin{array}{l}-148 \\
y_{13}^{1}\end{array}$ & $\begin{array}{l}320 \\
r^{2} \\
r^{\prime}\end{array}$ & $\begin{array}{l}370 \\
12 \\
12\end{array}$ & $\begin{array}{l}53 \mathrm{~T} \\
\mathrm{O}^{2} \\
\text { SY }\end{array}$ & $\begin{array}{l}100.0 \\
100.0 \\
100.3\end{array}$ & $\begin{array}{l}100.6 \\
100.9\end{array}$ \\
\hline Chloreform & o-chlestenniline & 0.3506 & $\begin{array}{l}\text { pot } \\
\text { phen } \\
\text { pyr }\end{array}$ & $\begin{array}{l}-20.4 \\
13\end{array}$ & $\begin{array}{l}3^{60} \\
0 \\
\text { IR }\end{array}$ & $\begin{array}{l}4^{(0)} \\
Y\end{array}$ & $\begin{array}{l}520 \\
\text { pale Y } \\
\text { pale Y }\end{array}$ & $\begin{array}{l}99.9 \\
97.7 \\
99.3\end{array}$ & 98.0 \\
\hline Chloroform & $2,4-1$ )ichloroaniline & 0.4771 & $\begin{array}{l}\text { pot } \\
\text { phen } \\
\text { pyr }\end{array}$ & $\begin{array}{l}-370 \\
y \\
13\end{array}$ & $\begin{array}{l}418 \\
0\end{array}$ & $\begin{array}{l}514 \\
\text { pale } y \\
\text { pale } y\end{array}$ & $\begin{array}{l}533 \\
\text { pale } Y \\
\text { pale Y }\end{array}$ & $\begin{array}{r}99.3 \\
\sim 97 \\
\sim 97\end{array}$ & \\
\hline Chlorobenzene & I-Naphthylamine & 0.0470 & $\begin{array}{l}\text { pot } \\
\text { phen } \\
\text { pyr }\end{array}$ & $\begin{array}{l}-340 \\
v \\
13\end{array}$ & $\begin{array}{l}268 \\
\mathrm{R} \\
\mathrm{R}\end{array}$ & $\begin{array}{l}105 \\
0 \\
0\end{array}$ & $\begin{array}{l}497 \\
Y \\
0 Y\end{array}$ & $\begin{array}{r}99.6 \\
99.6 \\
100.3\end{array}$ & 99.4 \\
\hline Chaloroben\%enc & $2,2^{\prime}-1$ Bipyridince & $\begin{array}{c}0.1726 \\
. .\end{array}$ & $\begin{array}{l}\text { pot } \\
\text { phen } \\
\text { pyr }\end{array}$ & $\begin{array}{l}-270 \\
13\end{array}$ & $\begin{array}{l}300 \\
i \\
J 1\end{array}$ & $\begin{array}{l}437 \\
i \\
p\end{array}$ & $\begin{array}{l}560 \\
y \\
y\end{array}$ & $\begin{array}{l}99.9 \\
90.7 \\
99.9\end{array}$ & 99.7 \\
\hline Chlorobenzene & $o-$ Chloreaniline & 0.2045 & $\begin{array}{l}\text { pot } \\
\text { phen } \\
\text { pyr }\end{array}$ & $\begin{array}{l}-170 \\
v \\
13\end{array}$ & $\begin{array}{l}381 \\
C \\
R\end{array}$ & $\begin{array}{l}488 \\
\text { OY } \\
\text { OY }\end{array}$ & $\begin{array}{l}5: 2 \\
Y^{\prime} \\
Y\end{array}$ & $\begin{array}{l}99.4 \\
100 \\
101\end{array}$ & \\
\hline
\end{tabular}

a Potentiometric titrations are clesignated by "pot"; unless otherwise noted, the glass and $\mathrm{Ag}-$ $\mathrm{AgCl}$ electrocles were immersed directly in the solution titrated. Visual titrations are indicated by the notation "phen" where ferrocyphen and by "pyr" where ferrocypyr was used as indicator.

"Colors: V(vinlet), I3(bluc), I'(purple), 1R(red), O(orange), OY'(golden), Y(yellow).

- Perchlorate salt precipitates cluring titration.

a Glass electrode $v$ s. $\Lambda \mathrm{g}-\Lambda \mathrm{gCl}$ in acetic anhydride silturated with lithium chloricle and silver chloricle as the refurence electrode.

Gencral procedure. Weigh out a $0.01-0.02$ mole sample of the base to be titrated, dissolve it in the solvent selected, and dilute to $250.0 \mathrm{ml}$ in a volumetric flask. Pipet $50.0 \mathrm{ml}$ of this solution into the titration vessel, add $50 \mathrm{ml}$ more of the solvent and $4 \mathrm{ml}$ of ferrocyphen or ferrocypyr inclicator solution, and titrate with standard perchloric acid solution. For titrations in acetic anhyclride use the $0.05 N$ perchloric acicl-acetic anhydride-acetic acid solution; for all others, use the standard o.I $N$ perchloric acid in acetic acid solution. Record both the potentiometric data and the solution color as a function of the titrant added. Then titrate successive aliquots visually using the appropriate color response of the indicator, ascertained from the first titration, to detect the equivalence point. Determine and correct for the amount of acid consumed by the inclicator; calculate the percent purity of the sample.

\section{Determination of formal redox potentials}

Solutions of the complexes, prepared in sulfuric acid of known concentration, were titrated potentiometrically using platinum and saturated calomer électrocles, 
standard ceric sulfate titrant, and a $5-\mathrm{ml}$ buret. Since the solid complexes were very slow to dissolve in the more dilute acid solutions, the weighed samples were first dissolved in $0.5 \mathrm{ml}$ of concentrated acid and then diluted with a known volume of sulfuric acid of the desired concentration. Some solutions were prepared by sha'zing an excess of the solid complex with the sulfuric acid for several min and then filtering off the undissolved solid. Although this did not permit use of weighed samples, it served to give crude estimates of solubilities and to check on the reliability of the other dissolution procedure. Limited solubility of the iron(II) complexes precluded potentiometric measurements both in neutral solutions and in acicl solutions more dilute than those employed here.

Formal reduction potentials (versus the standard hydrogen electrode) for the $\mathrm{Fe}(\mathrm{III}) / \mathrm{Fe}$ (II) complex systems and the $\mathrm{Ce}$ (IV)/Ce(III) couple were determined from the $50 \%$ and $200 \%$ experimental titration points, respectively. Potentiometric measurements prior to the end-point could be taken almost immediately after the adclition of each increment of titrant; beyond the end-point the electrode response was quite slow so that consiclerable time was required for the gradually increasing readings to attain reasonably constant values. The formal potentials found for the $\mathrm{Ce}(I V) / \mathrm{Ce}(\mathrm{III})$ couple may be slightly low in some cases for this reason. However the main interest in these was to test the reliability of the potentiometric measurements; in most cases the agreement with previously determined values is satisfactory. As a further check of the procedure, the amount of complex found was compared with that taken for titration. The results are compiled in lable II.

TABIIE II

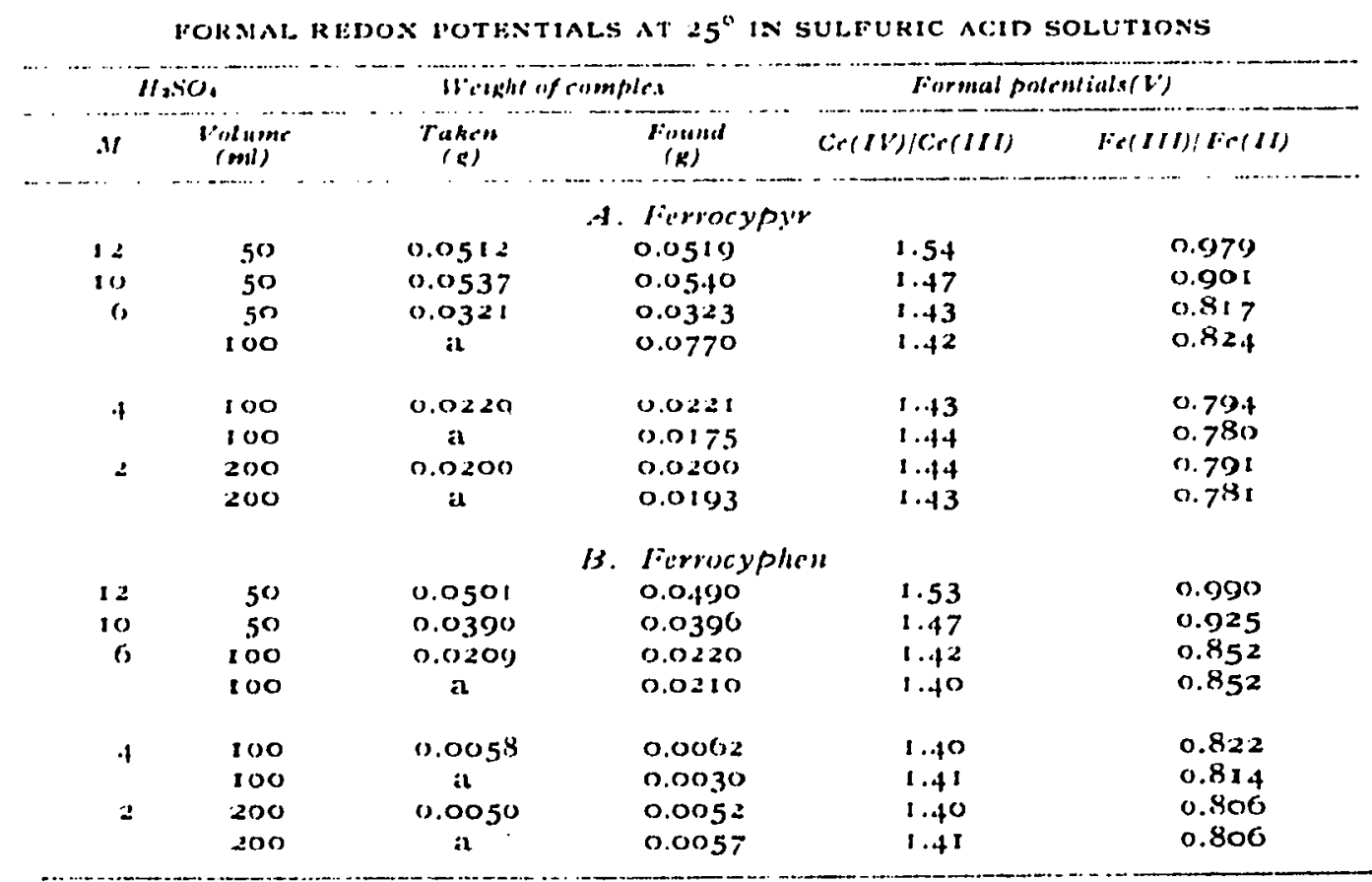

- Amount necessary to nearly saturate the solution with the complex; cxcess solid filtered off before titrating supernatant solution. 


\section{Oxidation-reduction titrations}

A brief survey of the more common oxidants and reductants was made to ascertain which would undergo sufficiently rapid reaction with the reduced and oxidized forms of the proposed indicators to be suitable in titrations. In strongly acidic solutions, ferrocyphen and ferrocypyr are oxidized reversibly and with great rapidity by $\mathrm{Ce}$ (IV), $\mathrm{V}(\mathrm{V}), \mathrm{Cr}_{2} \mathrm{O}_{7}^{-2}, \mathrm{BrO}_{3}^{-}$, $\mathrm{IO}_{4}^{-}$, or $\mathrm{HONO}$. Oxidation under similar conditions occurs much more slowly and at various rates using $\mathrm{IO}_{3}^{-}, \mathrm{H}_{2} \mathrm{O}_{2}, \mathrm{~S}_{2} \mathrm{O}_{8}^{-2}$, or $\mathrm{HNO}_{3}$. The oxidized indicators ferricyphen and ferricypyr are readily reduced in strong acid solutions by $\mathrm{Fe}(\mathrm{II}), \mathrm{Sn}$ (II), $\mathrm{Cu}(\mathrm{I}), \mathrm{Sb}(\mathrm{III}), \mathrm{I}^{-}$, and hydroquinone. Reduction by As(III), $\mathrm{SO}_{2}$, hydroxylamine, or hydrazine is extremely slow except in very dilute acid or neutral solutions.

All of the titrations were performed using ferrocyphen as the indicator. Since ferrocyplien and ferrocypyr have nearly identical formal reduction potentials and exhibit similar color changes on oxidation, it is assumed that they can be used interchangeably.

; Titralion of iron(II). Preliminary titrations, performed potentiometrically in the presence of added ferrocyphen, demonstrated the need for adcling phosphoric acid to lower the formal potential of iron(II) (and thus the equivalence point potential) so that the indicator response would coincide with potentiometric end-points. Subsequent titrations were performed according to the following directions: pipet ro.oo ml of the iron solution (in this case a solution containing 39.2 I6 $\mathrm{g}$ Mohr's salt per l), add $5 \mathrm{ml}$ of concentrated phosphoric acid followed by sufficient concentrated sulfuric or

IABI,F: III

STANDARDIZATION OF O.I $\mathrm{N} \mathrm{FeSO}_{4}$ USING YrRROCYIHEN INDICATOR

\begin{tabular}{|c|c|c|c|}
\hline Titrant & Solutions & End-polinl recognition & Normality \\
\hline $15_{2} \mathrm{Cr}_{2} \mathrm{O}_{7}$ & 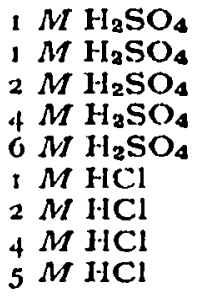 & $\begin{array}{l}\text { Potentiometric } \\
\text { Orange } \rightarrow \text { yellow green } \\
\text { Orange } \rightarrow \text { yellow green } \\
\text { Yellow green } \rightarrow \text { green } \\
\text { Green } \rightarrow \text { blue green } \\
\text { lndistinct color change } \\
\text { Yellow } \rightarrow \text { green } \\
\text { Yellow } \rightarrow \text { green } \\
\text { Indistinct color change }\end{array}$ & $\begin{array}{l}0.1001 \\
0.0999 \\
0.1000 \\
0.1002 \\
0.1004 \\
0.0999 \\
0.1001 \\
-\end{array}$ \\
\hline $\mathrm{HVO}_{3}$ & 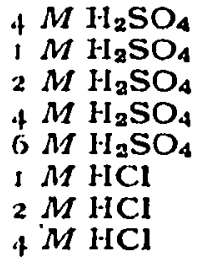 & $\begin{array}{l}\text { Potentiometric } \\
\text { Yellow } \rightarrow \text { pale blue } \\
\text { Yellow } \rightarrow \text { pale blue } \\
\text { Yellow } \rightarrow \text { pale blue } \\
\text { Yellow } \rightarrow \text { pale blue } \\
\text { Orange } \rightarrow \text { pale blue } \\
\text { Yellow } \rightarrow \text { pale green } \\
\text { Indistinct color change }\end{array}$ & $\begin{array}{l}0.1002 \\
0.0909 \\
0.1004 \\
0.1003 \\
0.1003 \\
0.1002 \\
0.1003 \\
-\end{array}$ \\
\hline $\mathrm{Cc}\left(\mathrm{SO}_{4}\right)_{y}$ & $\begin{array}{l}6 M \mathrm{H}_{2} \mathrm{SO}_{4} \\
1 M \mathrm{H}_{2} \mathrm{SO}_{4} \\
6 M \mathrm{H}_{2} \mathrm{SO}_{4} \\
1 M \mathrm{HCl} \\
2 M \mathrm{HCl} \\
4 M \mathrm{HCl}\end{array}$ & $\begin{array}{l}\text { Potentiometric } \\
\text { Orange } \rightarrow \text { pale blue } \\
\text { Yellow } \rightarrow \text { pale blue } \\
\text { Orange } \rightarrow \text { pale blue } \\
\text { Yellow } \rightarrow \text { pale yellow } \\
\text { Indistinct color change }\end{array}$ & $\begin{array}{l}0.1001 \\
0.0999 \\
0.1002 \\
0.1001 \\
0.0997 \\
-\end{array}$ \\
\hline
\end{tabular}


hydrochloric acid and water to give roo $\mathrm{ml}$ of the desired acid concentration, add I $\mathrm{ml}$ of indicator solution $(0.3 \mathrm{~g}$ ferrocyphen in $100 \mathrm{ml}$ of concentrated phosphoric acid, and titrate with standard oxidant to the first distinct, sharp change in color (see Table III for specific details). Blank titrations were made to correct for the amount of titrant necessary for oxidation of the indicator.

Tests performed on the solutions retained after titration showed the indicator reaction to be reversible. Prolonged storage in an excess of either oxidant or reductant produced no deleterious effect on indicator behavior.

Tilration of hydroquinone. Potentiometric titration of hydroquinone in the presence of added ferrocyphen with the vanadium(V) titrant demonstrated that the visual and potentiometric end-points coincide almost exactly, even as the acid concentration is varied. Using cerium(IV) as the titrant, visual end-points were observed to occur slightly before the potentiometric inflection points. The differences were in the range of rooo-2000 p.p.m. and hence are within the expected limits of experimentil error.

Visual titrations were performed according to the directions: weigh a $0.03-0.04-g$ sample, dissolve in $100 \mathrm{ml}$ of acid (either hydrochloric or sulfuric, $\mathrm{r}-6 \mathrm{M}$ ), add $\mathrm{I} \mathrm{ml}$ of indicator (0.3 $\mathrm{g}$ ferrocyphen in $100 \mathrm{ml}$ of concentrated sulfuric acid), and titrate with the standard oxidant to the first distinct, sharp change in color. Blank titrations are necessary to correct for the amount of titrant consumed by the indicator. The results are given in Table IV.

TABI.E IV

TITRIMETRIC ASSAY OF HYIROQUINONE USING FHRROCYPHEN INDICATOR

\begin{tabular}{|c|c|c|c|}
\hline Titrast & Solutioll & End.point rocosnilion & no f'urits' \\
\hline $\mathrm{Ce}\left(\mathrm{SO}_{4}\right)_{2}$ & $\begin{array}{l}\left.1 M \mathrm{H}_{2} \mathrm{SO}\right)_{4} \\
\left.6 M \mathrm{H}_{2} \mathrm{SO}\right)_{4} \\
1 M \mathrm{HCl} \\
1 M \mathrm{H}_{2} \mathrm{SO}_{4}\end{array}$ & $\begin{array}{l}\text { Orange } \rightarrow \text { colorless } \\
\text { Yellow } \rightarrow \text { very pale yellow } \\
\text { (.)range } \rightarrow \text { colorless } \\
\text { Potentiometric }\end{array}$ & $\begin{array}{r}99.4 \\
101.3 \\
99.9 \\
99.7\end{array}$ \\
\hline$H V$ & $\begin{array}{l}\text { I } \mathrm{HCl} \\
2 M \mathrm{HCl} \\
0.5 M \mathrm{H}_{2} \mathrm{SO}_{4} \\
4 M \mathrm{H}_{2} \mathrm{SO}_{4} \\
1 M \mathrm{HC} .1\end{array}$ & $\begin{array}{l}\text { Orange } \rightarrow \text { pale green } \\
\text { Yellow } \rightarrow \text { pale green } \\
\text { Orange } \rightarrow \text { pale green } \\
\text { Yellow } \rightarrow \text { pale green } \\
\text { Potentiometric }\end{array}$ & $\begin{array}{l}99.7 \\
99.6 \\
99.6 \\
99.5 \\
99.6\end{array}$ \\
\hline
\end{tabular}

Tests performed on the solutions retained after titration demonstrated that the indicator reaction behaves reversibly. Storage for several hours of the solutions to which an excess of either hydroquinone or titrant had been added was without noticeable effect on the indicator or its response.

Titration of primary aromatic amines. Samples of various amines were titrated using the following procedure: wcigh out a $2-3-\mathrm{mmol}$ sample of the amine, dissolve in Ioo $\mathrm{ml}$ of $6 \mathrm{M}$ hydrochloric acid, add $\mathrm{I} \mathrm{ml}$ of indicator solution ( $0.3 \mathrm{~g}$ ferrocyphen in IOo $\mathrm{ml}$ of concentrated hydrochloric acid), and titrate with standard sodium nitrite to a violet colored end-point that will persist for at least $3 \mathrm{~min}$. A titration blank was measured to correct for the amount of titrant consumed by the indicator. Results are given in Table $\mathrm{V}$. 
From the behavior of the indicator during the titrations it is evident that its reaction responds reversibly with respect to the titration reaction. Upon rapid addition of large increments of titrant, prior to the equivalence-point, ferrocyphen underwent complete and rapid oxiclation followed more slowly by a gradual return to the reduced

TABI.E V

TITKIMUTKIC ASSAY OF PRIMAKY AROMATIC AMINI:S USINC; HIRROCYPHIEN INDICATOR

\begin{tabular}{|c|c|c|c|}
\hline dininc & $M$ & Keplice & $\begin{array}{l}\text { ulc detcrminations } \\
\because \% \text { Jurity" }\end{array}$ \\
\hline Arilinc & 4 & 98.9 & $(98.9)$ \\
\hline Aniline & G & 90.3 & $99.599 .4 \quad(09.2)$ \\
\hline Anilinc & 8 & 90.3 & (09.1) \\
\hline Anilinc & y) & 90.2 & 90.9 \\
\hline p.l3romoaniline & 6 & 1000.1 & 90.7 \\
\hline o-Cinloroaniline & 6 & 09.0 & 100.1 \\
\hline I-Naplitliylamine & r) & & t) \\
\hline $2,4-$ IDichloroaniline & 6 & 100.2 & 100.1 \\
\hline
\end{tabular}

- Values given in parentheses were obtained by potentionctric titration.

- Visual end-point detection was impossible because titration gives colored products.

condition. Such behavior could be produced many times throughout the course of any given titration, and apparently, without adversely affecting the ability of the indicator to function properly. Since reduction of ferricyphen cannot be effected by the aromatic amines in question, it appears that one of the diazotization products or reaction intermediates is responsible for the reversibility of the indicator in this case. No attempt was made to eluciclate the indicator reaction mechanism.

Aniline was titrated potentiometrically in the presence of ferrocyphen to determine the color of the indicator in the immediate neighborhood of the electrometric endpoint. The change in color of the inclicator from light yellow to pale violet was observed to coincide almost exactly with the potentiometric encl-point in each of threc different hydrochloric acid concentrations employed : 4,6 and $8 M$. Consiclerable time, up to $I \mathrm{~h}$, was required to complete each potentiometric titration, because either or both chemical and electrode systems were slow to reach equilibrium and. of course, many equilibrium measurements were needed. No deleterious cffect on the reversibility of the indicator after this time was noticeable.

A moclest saving of time could be achieved by using $6 M$ hyclrochloric acicl as the solvent medium. Total clapsed time to complete the titration of aniline, for example, in $6 M \mathrm{HCl}$ by visual end-point detection was approximately Io min; in $4 M$ and $9 M$ acid the respective times averaged 5.5 and $10 \mathrm{~min}$.

\section{SUMMARY}

The neutral mixed ligatncl complexes dicyano-t)is-(1,10-phenanthroline)-iron(11) and dicyano-bis$\left(2,2^{\prime}\right.$-bipyridine)-iron(I1) are suitable indicators for the titration of various weak bases in nonaqueous solvents. They also serve as practical indicators for cortain redox titrations in acpucous solutions: their applicability in the cletermination of primary aromatic amines is especinlly noteworthy. Formal potentials of the complexes in different concentrations of sulfuric acid are reported; the results confirm earlicr finclings that the neutral iron(II) complexes form stable protonated species. 
RESUMLE

Les complexes fer (I I)-dicyano-bis-( $1,10-p h e ́ n a n t h r o l i n e)$ et fer(II)-dicyano-bis-(2,2'-dipyridine) conviennent tres bien, comme indicateurs aux titrages de diverses bases faibles en milieu nonaqueux, de mème qu'à certains titrages redox en solutions aqueuses ct tout spécialement au dosage d'amines aromatiques primaires.

\title{
ZUSAMMENFASSUNG
}

Die neutralen Mischkomplexe Dicyano-bis-( $1,10-p h e n a n t h r o l i n)-c i s e n(I I)$ und Dicyano-bis-(2,2'bipyridin)-eisen(II) eignen sich als Indikatoren fïr die Titration schwacher Basen in nichtwässrigen lösungsmittel sowje für gewisse Redox Titrationen in wässriger Lösung. $A u f$ ihre Anwendung bei der Bestimmung von aromatischen prinäiren $A$ minen wird hesonders hingewiesen.

\section{REFIRENCES}

1 A. A. Schilt, $J$. Am. Chem. Soc., 79 (1957) 5421.

2 A. A. Scurte, f. Am. Chem. Soc., 82 (1,960) 3000.

i A. A. ScHiLt, J.Am. Chenl. Soc., 82 (1960) 5779.

4 A. A. Scintr, $A$ nal. Chem., 30 (1958) 1409.

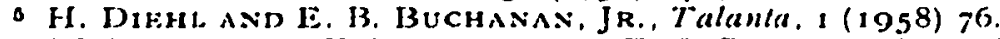

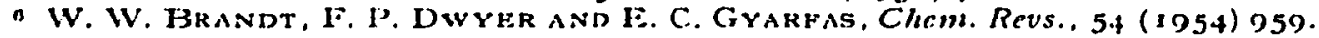

7 P. George, G. I. H. HaNANIA ANII D. H. IRVINI, J. Chem. Soc., (1959) 25.4.

n C. A. Streuli, Anal. Chem., 30 (1958) 997.

- J. S. Frerz, Acid-Basc Tilrations in Nonaqueous Solvents, G. Frederick Smith Chemical Co., Columbus, Ohio, 1952.

10 H. DiliL AND G. H. SMrth, Talanla, 2 (1959) 382.

Inal. Chiss. .1cla, $20(106.2) 13.4-143$

\section{REDUCTION OF AMMONIUM NITRATE WITH TITANIUM(III) CHLORIDE IN ACID MEDIA*}

\author{
IEUGENE A. BURNS
}

\begin{abstract}
Space Sciences and Propulsion Division, Startord Restarch Instilute, Mculo Park, Califormia(U.S.A.)
\end{abstract}

(Feceived May Gth, IgGI)

Investigation of the cletermination of nitrate in acid media using an indirect titanous titration has led to the proposal of a new mechanism of nitrate reduction. It las been shown that the reduction of nitrate to ammonium ion as proposed by $\mathrm{KNECHT} \mathrm{AND}$ HIBBARD ${ }^{1}$ is not quantitative when only a moderate excess (50 to $100 \%$ ) of the titanous salt is present.

TOMIEEX: reported that the direct potentiometric titration of nitrate solutions with titanous chloride is not possible because the reaction takes place very slowly. Therefore, to eliminate the time dependence when a small cxcess is present, a back-

- Part of the work presented in this paper was carricd out at the Jet Propulsion Laboratory, California Institute of 'Technology, under Contract No. NASw-6, sponsored by the National Acronautics and Space Administration. 